\title{
A SAGA DE VERITAS
}

Ir. Elvo Clemente*

Corria o ano de 1955; desde dezembro de 1954, o Prof. Irmão José Otão era Reitor. No triênio anterior fora Diretor da Faculdade de Filosofia, Ciências e Letras. Em seu diretorado realizaram-se vários doutorados em Pedagogia e em Letras. O Reitor cheio de idéias, de projetos, queria que a novel Universidade Pontifícia Católica do Sul não ficasse atrás das coirmãs que se anteciparam um lustro no Rio de Janeiro e em São Paulo. Resolveu, então, fundar a revista da Universidade VERITAS, pois o lema da alma mater é AD VERUM DUCIT (conduz ao verdadeiro).

Antes existiam duas publicações anuais: ANAIS e ANUÁRIO, desde os começos da pioneira Faculdade Livre de Ciências Políticas e Econômicas, em 1931 e depois de 1940 com a Faculdade Livre de Filosofia, Ciências e Letras. A Academia destinada a produzir saberes deve poder transmiti-los aos alunos que lhe freqüentam os bancos e à comunidade, em geral, através de textos escritos e veiculados em forma de livro ou revista. Assim é que o Prof. Ir. Faustino, vindo da Espanha em 1927, lecionando no Colégio Nossa Senhora do Rosário, a partir de 1931, foi secretário do Irmão Afonso idealizador e fundador dos cursos superiores maristas no Rio Grande do Sul. Logo em 1932 matriculou-se como aluno na Faculdade de Ciências Econômicas. Além das aulas no colégio, estudava as disciplinas do currículo acadêmico, reservando um tempo para os ANAIS da Faculdade e no fim do ano era editado o ANUÁRIO com fatos da vida acadêmica. Os ANAIS publicavam os resultados das pesquisas dos professores, eram substanciosos artigos sobre Economia, Política, Comércio, vida da cidade, problemas sociais, etc. Nos ANAIS, temos nomes de velhos mestres: Elpídio Ferreira Paes, Salomão Pires Abrahão, Renato Costa, Eloy José da Rocha, Colombo Rodrigues de Lima, Mem de Sá, Carlos Thompson Flores Neto, Felix Contreiras Rodrigues e outros. A partir de 1940, apareciam textos das ciências humanistas: Francisco Juruena, Dante de Laytano, Irmão Faustino, Armando Pereira da Câmara, Nelson Furtado, Amadeu de Oliveira Freitas, Alarich R. Schultz, Heinrich A. W. Bunse, Valdemar Colvero, Odilon Jaeger S. J, Ir. José Ignacio, Ir. Liberato e outros.

* Programa de Pós-Graduação em Letras, PUCRS.

\begin{tabular}{|l|l|l|l|l|l|}
\hline VERITAS & Porto Alegre & v. 50 & n. 4 & Dezembro 2005 & p. 277-278 \\
\hline
\end{tabular}


Em outubro de 1955, a revista VERITAS começou a receber os artigos dos professores das faculdades. O maior número de colaborações era dos cursos da Faculdade de Filosofia, Ciência e Letras. A estrutura administrativa era muito simples: Diretor e secretário, Irmão José Otão e Irmão Hilário Máximo (João Batista Camilotto). A partir de agosto de 1957, até 1975, Irmão Elvo Clemente secretariou a revista. Tarefa maior e decisiva, pois devia providenciar os artigos, revisálos e encaminhá-los à gráfica. Na direção, esteve presente, entre 1970 e 1978, o Irmão Roque Maria, que desenvolveu a revista na parte humanística e filosófica. De 1980 a 2004, a Revista Veritas esteve sob a direção do Irmão Nilo Berto, que teve, como revisor, o Irmão Demétrio André. Nestes anos todos, a revista manteve a regularidade em suas edições trimestrais. Aos poucos os artigos foram-se concentrando nas colaborações e investigações dos professores do Instituto de Filosofia e Ciências Humanas.

Com o surgimento do Programa de Pós-Graduação em Filosofia, a revista passou a ser o seu veículo de comunicação. Houve uma elitização da Revista pelo elevado nível dos temas apresentados, conseguindo ser referência nacional. O seu intercâmbio com as revistas congêneres de outros países aumentou consideravelmente.

Em seus 50 anos de existência na direção do Reitor Irmão José Otão e, atualmente, do diretor da Faculdade de Filosofia e Ciências Humanas, Prof. Dr. Draiton de Souza, a revista VERITAS recolhe os saberes e investigações filosóficas, auscultando as inquietações do homem finissecular e do alvorecer de 2000, com os olhos fixos e abertos na busca da VERDADE. 